\title{
Antibiosis Activity of Pantoea agglomerans Biocontrol Strain E325 Against Erwinia amylovora on Apple Flower Stigmas
}

\author{
P. L. Pusey, V. O. Stockwell, C. L. Reardon, T. H. M. Smits, and B. Duffy
}

First and third authors: U.S. Department of Agriculture, Agricultural Research Service, Tree Fruit Research Laboratory, Wenatchee, WA 98801; second author: Department of Botany and Plant Pathology, Oregon State University, Corvallis, OR 97330; and fourth and fifth authors: Agroscope Changins-Wädenswil ACW, Swiss National Competence Center for Fire Blight, CH-8820 Wädenswil, Switzerland. Accepted for publication 8 June 2011.

\begin{abstract}
Pusey, P. L., Stockwell, V. O., Reardon, C. L., Smits, T. H. M., and Duffy, B. 2011. Antibiosis activity of Pantoea agglomerans biocontrol strain E325 against Erwinia amylovora on apple flower stigmas. Phytopathology 101:1234-1241.

Pantoea agglomerans E325, the active ingredient in a commercial product for fire blight control, was previously shown in vitro to produce a unique alkaline- and phosphate-sensitive antibiotic specific to Erwinia amylovora. Antibiosis was evaluated as a mode of antagonism on flower stigmas using two antibiosis-deficient mutants. On King's medium B, mutants E325ad1 and E325ad2 have stable smooth-butyrous or hypermucoid colony morphologies, respectively, and the parental strain E325 exhibits phenotypic plasticity with predominantly hypermucoid colonies accompanied by slower-growing, smooth-butyrous colonies. Mutants

were tested against E. amylovora on stigmas of detached flowers of crab apple (Malus mandshurica) in growth chambers and apple (Malus domestica) in the orchard. Epiphytic fitness of the antibiosis-negative mutants was similar or greater than the parental strain as determined by relative area under the population curve (RAUPC). In laboratory and orchard trials, both mutants had significantly lower inhibitory activity against the pathogen (i.e., less reduction of E. amylovora RAUPC) compared with the parental strain. E325 and the mutants caused similar decreases in $\mathrm{pH}$ in a broth medium, indicating that acidification, which was previously reported as a possible mechanism of pathogen inhibition on stigmas, is not directly related to antibiosis. In this study we provide the first evidence for E325 antibiosis involved in E. amylovora growth suppression on apple flower stigmas.
\end{abstract}

The blossom blight phase of fire blight of apple and pear trees is generally initiated by epiphytic populations of Erwinia amylovora that become established on the stigmas of flowers $(36,43)$. The pathogen spreads from stigmas to the hypanthium in surface moisture and invades through the nectarthodes (41). The disease has been managed in recent decades through risk assessment (2) and the application of antibiotics to suppress E. amylovora on floral parts, but pathogen populations resistant to antibiotics, particularly streptomycin, have developed in many pome fruit production areas (23).

An alternative or complementary approach to the suppression of E. amylovora on flowers with antibiotics is the use of microbial antagonists (13). Antagonist populations have the capacity to increase in size and spread via pollinating insects, unlike antibiotics which have a relatively short residual limited to the contact area (40). To be effective, the antagonists must be applied to flowers early enough to colonize stigmatic surfaces in advance of the pathogen, compete for nutrients and, in many cases, produce compounds inhibitory to the pathogen (13). In 1996 Pseudomonas fluorescens strain A506, initially selected based on its preemptive exclusion of an ice-nucleating strain of Pseudomonas syringae on corn leaves (19), was the first commercialized antagonist for fire blight management (BlightBan A506; Nufarm Americas Inc., Burr Ridge, IL). Other microorganisms have since been evaluated and marketed for this purpose. Three Pantoea strains have been

Corresponding author: P. L. Pusey; E-mail address: Larry.Pusey@ars.usda.gov

doi:10.1094/PHYTO-09-10-0253

This article is in the public domain and not copyrightable. It may be freely reprinted with customary crediting of the source. The American Phytopathological Society, 2011 commercially developed for fire blight management including $P$. agglomerans $\mathrm{P} 10 \mathrm{c}$ marketed as BlossomBless in New Zealand (44), P. vagans C9-1 (syn. P. agglomerans C9-1) (11,22,31,32,37) registered as BlightBan C9-1 in the United States and Canada $(13,30)$, and P. agglomerans E325 marketed as Bloomtime FD in the United States and Canada (30).

Pantoea agglomerans strain E325 was selected from more than 1,000 isolates of bacteria and yeasts evaluated for their capacity to suppress E. amylovora on the stigmatic surfaces of crab apple flowers $(24,25,29)$. Like other microbial strains studied (13), E325 is an excellent colonizer of stigmatic tissue $(26,27)$ and likely competes with the pathogen for space and nutrients. Given the high efficacy of this antagonist on flowers, antibiosis was suspected, but not detected consistently in vitro until assays were done with partial stigma-based medium (PSBM), a low phosphate medium with nutrients identified in stigma exudates from apple and pear flowers $(28,30)$. Activity of the E325 antibiotic (30) was (i) specific to E. amylovora, (ii) unaffected by amino acids or enzymes known to affect other antibiotics of Pantoea strains, (iii) sensitive to alkaline conditions, and (iv) unstable in the presence of phosphate concentrations conventionally used in antibiosis assays. Chemical characterization indicates a peptidic compound with a molecular weight of about $555 \mathrm{Da}(30)$.

The role of antibiotics produced by strains of $P$. agglomerans in suppressing $E$. amylovora has been evaluated on flowers in three laboratory studies $(5,7,47)$ and one field study (39). El-Masry et al. (5) transformed Escherichia coli with a plasmid from $P$. agglomerans, giving it the ability to reduce pathogen growth and symptom development on inoculated hawthorn flowers. Wright et al. (47) generated a mutant of strain Eh318 deficient in two antibiotics, and subsequently demonstrated its inferiority to the parental strain in reducing fire blight on greenhouse-grown apple flowers. Giddens et al. (7) showed that a mutant of Eh1087 de- 
ficient in a phenazine antibiotic was less effective than the parent strain in suppressing E. amylovora on apple flowers in the greenhouse and laboratory. In a field study by Stockwell et al. (39), the overall effectiveness of strain Eh252 in reducing disease incidence on pear and apple was greater than that of an antibioticdeficient mutant derived from Eh252, indicating the importance of antibiosis as a mechanism in biological control of fire blight.

Before researchers focused on antibiosis as a mechanism in biological control of fire blight, some investigators proposed that bacteria fitting the description of Pantoea spp. inhibit E. amylovora by acidification of apple and pear tissues $(6,8)$, including floral surfaces (33). Wodzinski et al. (46) demonstrated, however, that strains of $P$. agglomerans differing in ability to inhibit $E$. amylovora on pear fruit did not cause a corresponding effect on $\mathrm{pH}$ in fruit tissue or in a complex medium. When acid production as a mode of biological control was recently revisited in the case of $P$. agglomerans E325 (30), the $\mathrm{pH}$ of extracted stigma exudates indicated slight increases in acidity caused by strain E325 on flowers in the orchard. Acidification by E325 is also of interest in connection with antibiosis (30), because the activity of the unique antibiotic of E325 was highly stable in acidic environments, but irreversibly eliminated under alkaline conditions.

The primary objective of this study was to determine whether the antibiotic of E325 is produced and active against E. amylovora on the stigmatic surfaces of pomaceous flowers. A secondary objective was to investigate the possible relationship between antibiosis and previously reported acidification by E325 on stigmas (30). Our approach was to compare P. agglomerans strain E325 with two antibiosis-deficient mutants.

\section{MATERIALS AND METHODS}

Bacterial strains. $P$. agglomerans strain E325 used in this study is a spontaneous rifampicin- and streptomycin-resistant mutant of the wild-type strain that was isolated from 'Gala' apple flowers near Wenatchee, WA in 1994 (24). The rifampicin- and streptomycin-resistant mutant is the strain in Bloomtime FD (Northwest Agricultural Products, Pasco, WA). The primary pathogen strain was E. amylovora Ea153N, a nalidixic acid-resistant strain obtained from K. Johnson (Oregon State University, Corvallis) (14). A kanamycin-resistant strain of E. amylovora, Ea7/74(pfdC1Z'-lux), obtained from K. Geider (Federal Research Centre for Cultivated Plants, Quedlinburg, Germany) (3), was used for screening to identify antibiosis-deficient mutants of $P$. agglomerans E325.

Bacteria were cultured on nutrient yeast dextrose agar (NYDA; $8 \mathrm{~g}$ of nutrient broth, $5 \mathrm{~g}$ of yeast extract, $5 \mathrm{~g}$ of dextrose, and $15 \mathrm{~g}$ of agar in 1 liter of deionized water) for $24 \mathrm{~h}$ at $24^{\circ} \mathrm{C}$. Cell suspensions were prepared in $10 \mathrm{mM}$ phosphate buffer $(\mathrm{pH} 7)$ and $0.03 \%$ Tween 20 by adjusting to 0.1 optical density at $600 \mathrm{~nm}$ using a spectrophotometer (Spectronic 20; Milton Roy Co., Rochester, NY) giving a cell concentration of $1 \times 10^{8} \mathrm{CFU} / \mathrm{ml}$. The medium PSBM (25 g of glucose, $25 \mathrm{~g}$ of fructose, $0.2 \mathrm{~g}$ of amino acid mix [proline, asparagine, glutamine, and serine in ratio of $3: 2: 2: 1], 0.8 \mathrm{~g}$ of $\mathrm{NH}_{4} \mathrm{Cl}, 0.3 \mathrm{~g}$ of $\mathrm{K}_{2} \mathrm{HPO}_{4}, 0.1 \mathrm{~g}$ of $\mathrm{NaH}_{2} \mathrm{PO}_{4}, 0.4 \mathrm{~g}$ of $\mathrm{MgSO}_{4}$, and $1.2 \mathrm{mg}$ of nicotinic acid in 1 liter of deionized water, $\mathrm{pH} 7$ ) was used in the form of broth or agar (15 g/liter) for detection of antibiosis (30).

Mutagenesis and sequence analysis. Antibiosis-deficient mutants of E325 were generated using the EZ-Tn5<KAN-2>Tnp Transposome Kit (Epicentre Biotechnologies, Madison, WI). Standard procedures were used for electroporation (34) with a Gene Pulser Xcell Electroporation System (Bio-Rad Laboratories, Hercules, CA). Mutants appearing on NYDA amended with kanamycin $(25 \mu \mathrm{g} / \mathrm{ml})$ were transferred to PSBM amended with kanamycin $(25 \mu \mathrm{g} / \mathrm{ml})$ and seeded with the kanamycin-resistant pathogen E. amylovora Ea7/74(pfdC1Z'-lux) at a final concentration of $5 \times 10^{8} \mathrm{CFU} / \mathrm{ml}$. The first antibiosis-deficient mutant selected, designated E325ad1, was later found to be morphologically different from the parental strain on certain media, including King's medium B (18), which led to the selection of a second mutant, E325ad2.

Genomic DNA of antibiosis-deficient mutants was isolated with the MasterPure DNA \& RNA Purification Kit (Epicentre Biotechnologies, Madison, WI) and digested with EcoRI (New England Biolabs, Ipswich, MA). Fragments were cloned into the vector pZErO-1 with Zeocin resistance (Invitrogen, Carlsbad, CA) and introduced into chemically competent TOP10 cells (TOPO TA Cloning Kit for Sequencing, Invitrogen, Carlsbad, CA). Cells were plated on Luria-Bertani (Lennox) agar amended with both Zeocin $(50 \mu \mathrm{g} / \mathrm{ml})$ and kanamycin $(25 \mu \mathrm{g} / \mathrm{ml})$ for selection of transformants harboring the transposon-containing fragment. Plasmid DNA of transformants was extracted with the FastPlasmid Mini Kit (Eppendorf, Westbury, NY) and DNA flanking the insertion was sequenced with a GenomeLab DTCS Quick Start Kit (Beckman Coulter, Fullerton, CA) and a CEQ 8000 Genetic Analysis System capillary-based DNA Sequencer (Beckman Coulter) using the transposon-specific primers KAN-2 RP-1 and KAN-2 FP-1 (Epicentre Biotechnologies).

Regions flanking the insertion sites of the transposon were extracted from the draft genome sequence of $P$. agglomerans E325 using different subroutines of the Lasergene package, version 8.1.5 (DNASTAR, Madison, WI). Coding sequences (CDS) were manually annotated and the annotation was optimized using the GenDB annotation of related CDS in the genome of $P$. vagans C9-1 $(37,38)$. Pathway identification was done using the KEGG pathway tool (16) incorporated in GenDB (20).

Detached flower assays. Laboratory experiments were performed with detached flowers of Manchurian crab apple (Malus mandshurica [Maxim.] Kom.) as previously described (24). The cut end of the flower pedicle was submerged in $10 \%$ sucrose contained in a 2-ml vial, and the vials were placed inside a 4-liter container.

The newly opened crab apple flowers were treated with $P$. agglomerans E325, antibiosis-deficient mutant or with water only as a control. Inoculum was applied by touching each of five stigmas per flower with a 0.1 - to $0.2-\mu$ l suspension $\left(10^{8} \mathrm{CFU} / \mathrm{ml}\right)$ forming a thin film of moisture. Flowers were incubated at $90 \%$ relative humidity and $14^{\circ} \mathrm{C}$, which is a realistic average orchard temperature during bloom in Washington State. After $48 \mathrm{~h}$, all flowers were inoculated with Ea153N $\left(10^{7} \mathrm{CFU} / \mathrm{ml}\right)$ using the same method by which flowers were treated with $P$. agglomerans. Flowers were sampled on 1, 2, 4, 6, 8, and 10 days after treatment with $P$. agglomerans. Sampling at 2 days occurred about $1 \mathrm{~h}$ after inoculation with Ea153N. To estimate population size, stigmas and styles of individual flowers were placed in sterile microcentrifuge tubes containing $1 \mathrm{ml}$ of sterile buffer $(10 \mathrm{mM}$ potassium phosphate, $\mathrm{pH} 7$ ). Tubes were vortexed briefly and placed in a sonication bath for $60 \mathrm{~s}$. Samples were again vortexed, and serial dilutions spread on trypticase soy agar (TSA; $15 \mathrm{~g}$ of tryptone, $5 \mathrm{~g}$ of soytone [Difco Laboratories, Detroit], $5 \mathrm{~g}$ of $\mathrm{NaCl}$, and $15 \mathrm{~g}$ of agar in 1 liter of deionized water) amended with rifampicin $(25 \mu \mathrm{g} / \mathrm{ml})$ and cycloheximide $(50 \mu \mathrm{g} / \mathrm{ml})$ for detection of $P$. agglomerans and on CCT medium (10) amended with nalidixic acid $(100 \mu \mathrm{g} / \mathrm{ml})$ for detection of Ea153N. Five flowers were sampled per treatment on each date. The experiment was performed twice in 2009 with one mutant (E325ad1) and twice in 2010 with two mutants (E325ad1 and E325ad2).

Orchard trials. Orchard experiments were conducted in 2009 in separate orchard blocks of 'Gale Gala' and 'Golden Supreme' apple (Malus domestica Borkh.) planted in 2001 and 1998, respectively, at Columbia View experimental orchards north of Wenatchee, WA. Similar tests were done in 2010 in separate blocks of 'Royal Gala' and 'Cameo' planted in years 2003 and 2001, respectively, at the Columbia View orchards. The blocks were selected based on quantity and timing of bloom. In each 
year, we selected blocks with relatively early and late bloom development to minimize overlap in sampling periods.

Prior to treatment branches were tagged for use, and older flowers ( $>50 \%$ of anthers dehisced) and all unopened flowers or buds were removed. This ensured that only newly opened flowers were treated in each experiment. Suspensions of P. agglomerans and Ea153N were prepared at the same concentrations as used in the laboratory, but applied to stigmas with an artist brush (year 2009) or sterile swab (year 2010). Flowers were sampled on 1, 2, 3, 4, 6, and 8 days after treatment with $P$. agglomerans. Sampling at 2 days was performed approximately 1 to $3 \mathrm{~h}$ after inoculation with Ea153N. Population sizes were determined as already described, except serial dilutions were spread on three media: King's B (year 2009) or TSA (year 2010) amended with rifampicin $(25 \mu \mathrm{g} / \mathrm{ml})$ and cycloheximide $(50 \mu \mathrm{g} / \mathrm{ml})$ to enumerate E325 and derivatives; King's B (year 2009) or TSA (year 2010) amended with kanamycin $(50 \mu \mathrm{g} / \mathrm{ml})$, rifampicin, and cycloheximide for selective recovery of the derivative strains; and CCT to detect the pathogen. King's B was replaced with TSA to avoid the excessive production of extracellular polysaccharides of E325 and E325ad2 that may interfere with colony counts. Five single-tree replicates were used per treatment in a completely randomized block, and six flowers were collected per tree on each sampling date. In 2009 , the experiment was performed from 25 April to 3 May on 'Gale Gala' apple, and from 1 May to 9 May on 'Golden Supreme' apple; in year 2010, the experiment was performed from 20 April to 28 April on 'Royal Gala' apple, and from 23 April to 1 May on 'Cameo' apple.

Weather data were collected with a WatchDog Data Logger (Model 450; Plainfield, IL). In 2009, overall average temperature in orchard blocks of 'Gale Gala' and 'Golden Supreme' apple during the sampling period was 11.2 and $11.6^{\circ} \mathrm{C}$, respectively (Fig. 1A); overall average relative humidity was 45.7 and $53.2 \%$, respectively (Fig. 1C). Brief rain events occurred in the 'Golden Supreme' block totaling $2.0 \mathrm{~mm}$ (Fig. 1E), but rainfall was not detected in the 'Gale Gala' block. In 2010, overall average temperature in test blocks of 'Royal Gala' and 'Cameo' apple during the sampling period was 13.0 and $12.4^{\circ} \mathrm{C}$, respectively (Fig. 1B); overall average relative humidity was 41.2 and $38.1 \%$, respectively (Fig. 1D). Total rainfall in each of the year 2010 blocks was $3.0 \mathrm{~mm}$ (Fig. 1F). Petal fall in all blocks generally started at between 6 and 8 days from the beginning of each experiment.

Acidification and antibiotic production in PSBM broth. Acidification by E325 and antibiosis-deficient derivatives was compared in PSBM broth. As in the laboratory flower experiment,

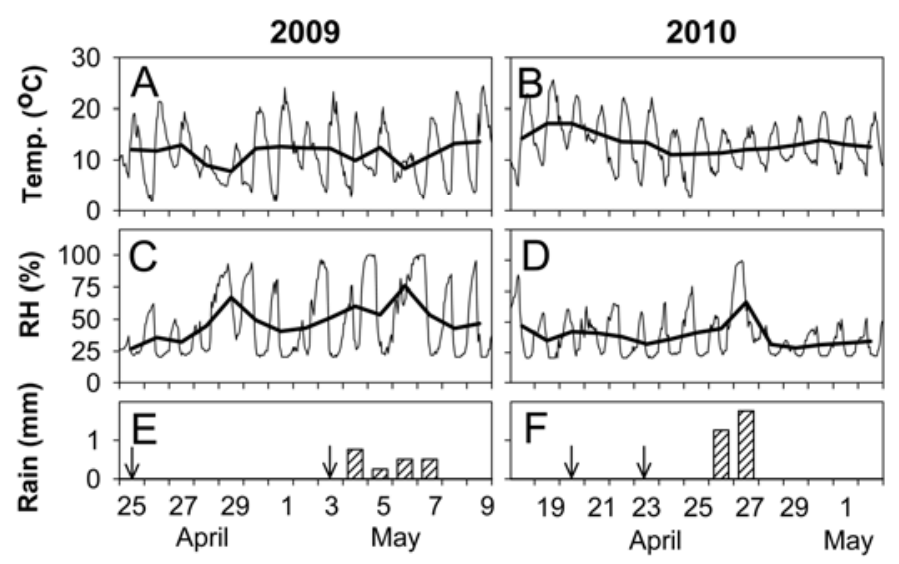

Fig. 1. Environmental conditions in apple orchards near Wenatchee, WA in 2009 and 2010 for comparing Pantoea agglomerans E325 with antibiosisdeficient mutants as antagonists against Erwinia amylovora Ea153N on flowers. $\mathbf{A}$ and $\mathbf{B}$, Temperature and $\mathbf{C}$ and $\mathbf{D}$, relative humidity data are presented at hourly intervals (thin line) and as daily averages (bold). $\mathbf{E}$ and $\mathbf{F}$, Rainfall is presented as daily totals. Arrows indicate start date of each of four trials that extend for 8 days. cultures were incubated at $14^{\circ} \mathrm{C}$. Each bacterial strain was cultured on NYDA and suspended in PSBM broth at $10^{5} \mathrm{CFU} / \mathrm{ml}$. The inoculated medium was distributed to individual sterile culture tubes $(150 \mathrm{~mm} \times 20 \mathrm{~mm}), 4 \mathrm{ml}$ per tube. The tubes were placed on a rack with a $20^{\circ}$ incline and incubated on a rotary shaker set at $150 \mathrm{rpm}$. Three tubes per strain were sampled after $18,24,42,48,72,96$, and $120 \mathrm{~h}$. Population size was determined after each time period by transferring $111 \mu \mathrm{l}$ from each culture tube to a sterile microcentrifuge tube containing $1 \mathrm{ml}$ of sterile buffer (10 mM potassium phosphate, $\mathrm{pH} 7$ ) and spreading serial dilutions on TSA. For $\mathrm{pH}$ measurement and antibiotic detection, $1 \mathrm{ml}$ was withdrawn from each culture tube and centrifuged at $16,000 \times g$ for $5 \mathrm{~min}$.

The supernatant was transferred to a clean tube, and $\mathrm{pH}$ was measured with an Accumet AP63 pH meter and Accumet Combination MicroProbe, 13-620-96 (Fisher Scientific, Pittsburgh, PA). Each 1-ml sample was absorbed onto a C-18 Classic SepPak (Waters, Millford, MA), the column was rinsed with $1.5 \mathrm{ml}$ of water followed by $0.5 \mathrm{ml}$ of $5 \% \mathrm{MeOH}$, and then the component comprising the antibiotic (if present) was eluted with $1 \mathrm{ml}$ of $20 \% \mathrm{MeOH}$. This fraction was filtered through a $0.2 \mu \mathrm{l}$ PVDF filter (Millex-GV; Millipore Corp., Bedford, MA), stored at $-80^{\circ} \mathrm{C}$ for 1 to 10 days, dried with a Speed Vac Concentrator (Savant Instruments, Inc., Farmingdale, NY), and then reconstituted in $20 \mu \mathrm{l}$ of water. A series of one-half dilutions was prepared, and then activity assays were performed as previously described (30) by pipetting $10 \mu \mathrm{l}$ of each dilution into wells (1.5-mm diameter) in PSBM agar. After the aqueous sample diffused into the agar, the medium was overlaid with $4 \mathrm{ml}$ of soft PSBM $\left(0.8 \%\right.$ agar) containing $100 \mu \mathrm{l}$ of $\approx 10^{9} \mathrm{CFU} / \mathrm{ml}$ of Ea $153 \mathrm{~N}$. The plates were incubated overnight at $28^{\circ} \mathrm{C}$ and examined for the presence or absence of inhibition zones surrounding wells. The inverse of the dilution end point of each sample was recorded as activity units.

Data analysis. Population data were transformed to $\log _{10}$ prior to analysis. For laboratory experiments, mean values and standard errors were calculated by averaging values for single flowers or PSBM cultures sampled on one date. For orchard tests, population sizes on flowers of each tree were averaged before calculating the mean and standard error for replicate trees. To compare the growth of $P$. agglomerans E325 and antibiosis-deficient derivative strains, or to evaluate differences in their effect on the growth of Ea153N, the relative area under the population curve (RAUPC) of bacteria was calculated for each replicate set or tree, using the following formula $(35,39)$ :

$$
R A U P C=\frac{\sum_{i=1}^{n}\left(\frac{y_{i}+y_{i-1}}{2}\right) \times\left(t_{i}-t_{i-1}\right)}{t_{n}-t_{i}}
$$

where $y$ is the mean population size of a bacterial strain on the $i$ th sample date and $t$ is the corresponding sample time.

Data were subjected to analysis of variance using SAS version 9.2 (SAS Institute, Cary, NC) and mean values were separated according to the least significant difference (LSD) test $(P=0.05)$.

\section{RESULTS}

Generation of antibiosis-deficient mutants. Two mutants of E325 (designated E325ad1 and E325ad2) that were deficient in antibiosis to $E$. amylovora were obtained from a set of approximately 3,000 transposon mutants tested. Each mutant had a single insertion of Tn5. The flanking region of the transposon insertion site was compared to the annotated genome sequence of $P$. vagans C9-1 $(37,38)$. For mutant E325ad1, the insertion was identified in a putative oxidoreductase with the $P$. vagans C9-1 locus tag Pvag_3594 (Fig. 2); whereas the transposon in mutant E325ad2 integrated in a corresponding gene of $P$. vagans C9-1, 
Pvag_0267, encoding a protein involved in the methionine salvage pathway. Both regions disrupted in the mutants of E325, thus, are also present in the genome of $P$. vagans C9-1. Since C91 does not produce the antibiotic of E325 (11,30), it is unlikely that the genes harboring the insertion are involved directly in the biosynthesis of the E325 antibiotic.

On King's medium B after 24 to $36 \mathrm{~h}$ at $24^{\circ} \mathrm{C}$, the mutant designated E325ad1 consistently formed smooth and butyrous colonies. The other mutant, E325ad2, had hypermucoid and viscous colonies on this medium. The parental strain E325 exhibits phenotypic plasticity with predominantly hypermucoid and viscous colonies accompanied by a minority of slower-growing, smooth and butyrous colonies. These two colony forms of E325 were not separable by subculturing, and the transfer of a single colony always resulted in dual-colony morphotypes. No relationship was indicated between colony characteristics and antibiotic production during screening assays to detect antibiosis-deficient mutants.

Antibiosis on detached flowers. Each of two experiments, one involving mutant E325ad1 (year 2009), and a later one involving mutants E325ad1 and E325ad2 (year 2010), were performed twice and the data were pooled. In the 2009 experiment, mean population sizes of E325 and E325ad1 were similar (Fig. 3A); however, at 1, 6, and 10 days, population sizes of E325ad1 were slightly larger $(P=0.05)$ than those of E325. In the 2010 experiment, mean population sizes of the parent and derivative strains were not different (Fig. 3B), except on day 10, when mean population size of E325ad1 was greater $(P=0.05)$ than that of the other strains. A comparison of RAUPC values representing data on all sampling days showed that in 2009 the RAUPC of E325ad1 was slightly greater $(P=0.05)$ than that of E325, but in 2010 no differences in RAUPC were indicated among the three genotypes of E325 (Table 1).

In both experiments, mean population sizes of E. amylovora were always larger $(P=0.05)$ on flowers treated with the antibiosis-deficient mutants of E325 than on flowers treated with the parental E325 (Fig. 3C and D) after the first sample (which occurred on the same day as inoculation with the pathogen and 2 days after treatment with $P$. agglomerans). An exception was with populations enumerated on day 10 in the 2009 experiment (Fig. 3C) that indicated no difference between treatments with E325ad1 and E325. Also, after the initial sampling, pathogen population sizes on flowers treated with the mutant strains were smaller $(P=0.05)$ than those on control flowers treated with water (Fig. 3C and D). In the 2010 experiment, mean population sizes of Ea153N on flowers treated with the two antibiosis-deficient mutants were not different from each other on any samp- ling day. The above results are consistent with Table 1, indicating that the antibiosis-deficient mutants of E325 reduced the RAUPC of Ea153N compared with growth of the pathogen on watertreated detached flowers, but mutants were less suppressive to the pathogen $(P=0.05)$ than the parent strain.

Antibiosis on orchard flowers. Mean population sizes of E325 and E325ad1 on flowers of 'Gale Gala' and 'Golden Supreme' were similar in 2009 (Fig. 4A and B); however, on flowers of 'Gale Gala', population sizes of E325ad1 were larger $(P=0.05)$ than those of E325 at 1 and 3 days (Fig. 4A). In 2010, on 'Royal Gala' flowers, no difference was indicated between population sizes of E325 and those of the antibiosis-deficient mutants on any sampling day (Fig. 5A), except for a slight difference $(P=0.05)$ between the mutants at 2 days. On 'Cameo' flowers in 2010, differences $(P=0.05)$ were indicated between population sizes of E325 and those of one or both mutant strains during the sampling

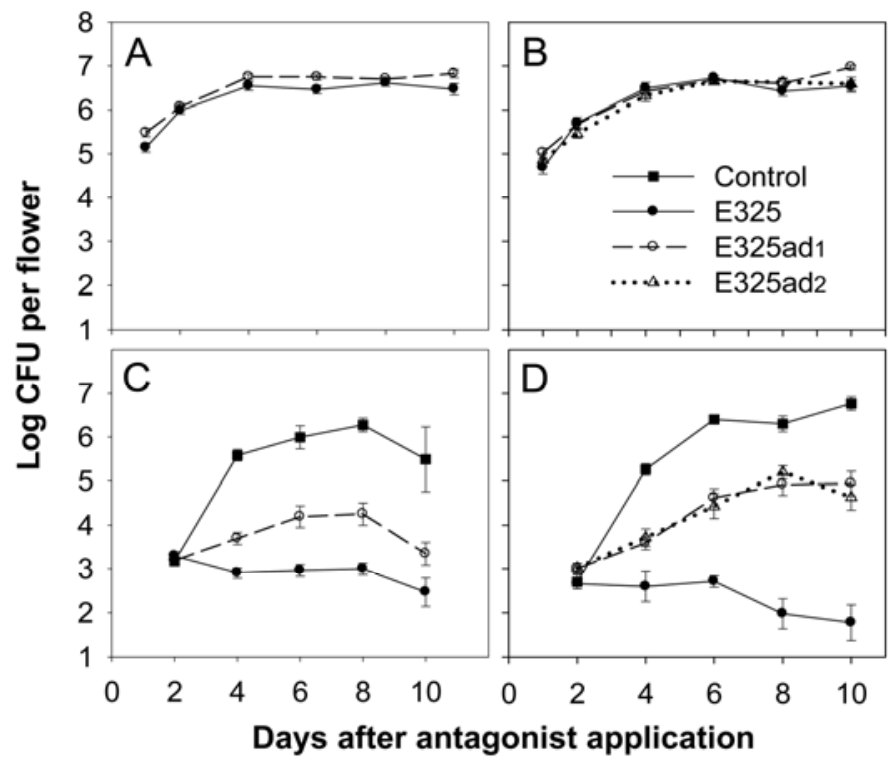

Fig. 3. Comparison of Pantoea agglomerans E325 with antibiosis-deficient mutants (E325ad1 and E325ad2) of this strain as antagonists of Erwinia amylovora Ea153N on stigmas of detached crab apple flowers held at $14^{\circ} \mathrm{C}$ and $90 \%$ relative humidity. Tests were done in A and C, 2009 with E325ad1 and in $\mathbf{B}$ and D, 2010 with both E325ad1 and E325ad2. Population sizes are shown $\mathbf{A}$ and $\mathbf{B}$, for strains of $P$. agglomerans and $\mathbf{C}$ and $\mathbf{D}$, for the pathogen. Stigmas were inoculated with $P$. agglomerans at 0 days and with Ea153N at 2 days. Each point is the mean of 10 flowers, and vertical lines represent standard error.
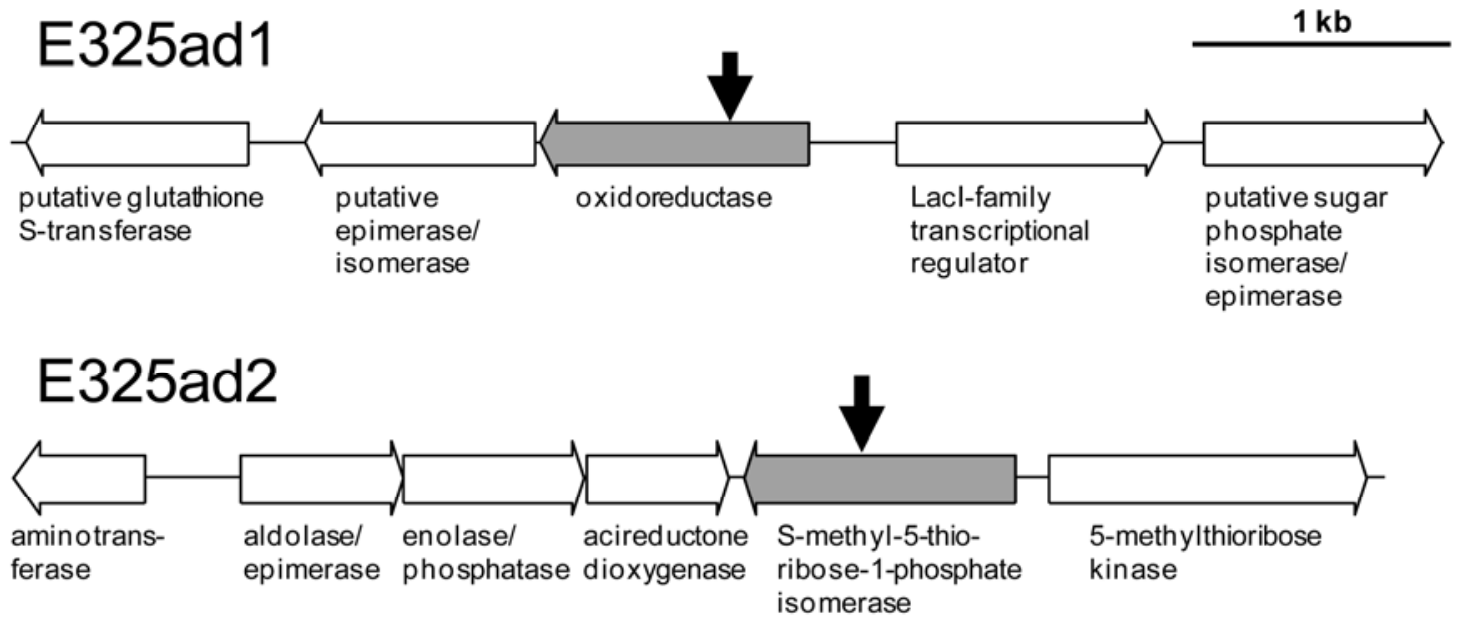

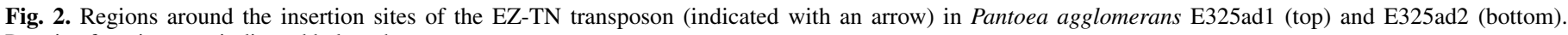
Putative functions are indicated below the genes. 
period from 1 to 4 days (Fig. 5B), but mutant strains were not significantly different from each other. In three of the apple orchard blocks, RAUPC values for E325 and derivative strains were not significantly different (Table 1); however, in the 'Cameo block', RAUPC values for the antibiosis-deficient mutants were slightly greater than that of the parent strain.

Mean population sizes of Ea153N on apple flowers treated with $P$. agglomerans were similar on the initial sampling day shortly after inoculation with the pathogen (2 days after treatment with $P$. agglomerans). On flowers of 'Gale Gala' in 2009, pathogen population sizes at 3 and 4 days were similar, though at 4 days, mean values for the pathogen on E325ad1-treated flowers were slightly greater $(P=0.05)$ than those on water-treated and E325treated flowers (Fig. 4C). In the trial with 'Golden Supreme', however, pathogen population sizes at 3 and 4 days were greater on water-treated and E325ad1-treated flowers than on E325treated flowers (Fig. 4D). After 4 days, statistical separations of mean population sizes of the pathogen were the same in the two orchard trials in 2009 (Fig. 4C and D); at 6 days, mean values of the pathogen for all three treatments were different from each other, and at 8 days, mean values of the pathogen on control and E325ad1-treated flowers were not different from each other but greater $(P=0.05)$ than those for E325-treated flowers. The RAUPC of Ea153N for E325ad1-treated flowers was greater than that for E325-treated flowers in both orchard trials in 2009 (Table 1). Compared with growth of the pathogen on water-treated flowers, E325ad1 reduced the RAUPC of Ea153N in the trial with 'Golden Supreme', but not in the trial with 'Gale Gala'.

In the 2010 orchard trials, mean population sizes of Ea153N on flowers of 'Royal Gala' and 'Cameo' were not different on the initial sampling day (2 days after treatment) or at 3 days (Fig. 5C and D). During the period from 4 to 8 days, population sizes of the pathogen on E325-treated flowers were substantially smaller $(P=0.05)$ than those on flowers subjected to all other treatments; no differences were indicated among treatments involving the mutants or water, except in the case of 'Royal Gala' at 4 days (Fig. 5C) when pathogen populations on E325ad2-treated flowers were smaller $(P=0.05)$ compared with water-treated flowers. Similarly, in the 'Royal Gala' block, the RAUPC of Ea153N on E325-treated flowers was significantly reduced compared with the other treatments, which were not different from each other (Table 1). In the 'Cameo' block, however, both E325ad1 and E325ad2 slightly reduced the RAUPC of Ea $153 \mathrm{~N}$ compared with the watertreated control.

Acidification and antibiotic production in PSBM broth. Growth of $P$. agglomerans E325 and antibiosis-deficient mutants in PSBM broth was similar (Fig. 6A and B) and mean RAUPC values did not differ significantly $(P=0.05$, data not shown). The bacteria reached stationary phase by $48 \mathrm{~h}$. As bacteria transitioned from exponential to stationary growth phase (between 42 and 48 h), there was a corresponding decrease in $\mathrm{pH}$ that reached a low of about pH 3 by $72 \mathrm{~h}$ (Fig. 6C and D). At each sampling time, $\mathrm{pH}$ values for cultures of the antibiosis-deficient mutants were not different $(P=0.05)$ from those of the parent strain. The antibiotic was detected only in cultures of the E325 parent strain and only in samples collected at $72 \mathrm{~h}$ or later (Fig. 6E and F).

\section{DISCUSSION}

This study provides evidence that antibiosis is a mechanism of $P$. agglomerans $\mathrm{E} 325$ in the suppression of E. amylovora on flower stigmas. Further, in vitro experiments showed that acidification by E325 is not directly related to antibiosis, though it likely favors antibiotic stability. Antibiosis by strain E325 was supported by laboratory and orchard experiments with two antibiosis-deficient mutants of E325. While we can report impairment of antibiosis activity, neither gene disrupted by Tn5 insertion is directly linked to biosynthesis of the uncharacterized E325 antibiotic.

Both mutants showing impaired antibiosis activity exhibited normal fitness on floral surfaces based on growth that was similar

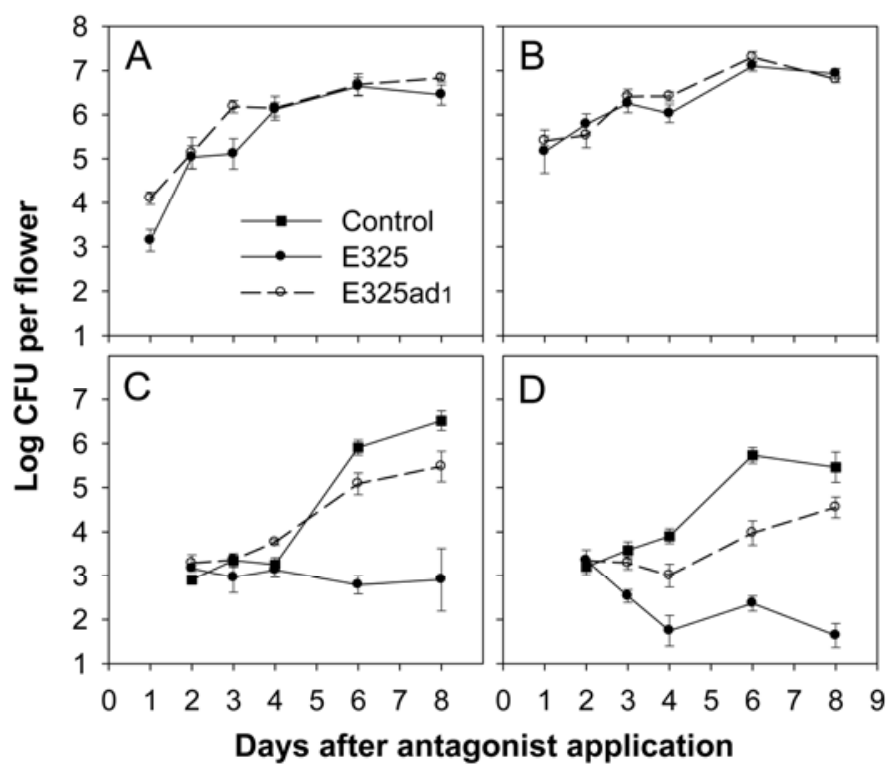

Fig. 4. Comparison of Pantoea agglomerans E325 with an antibiosis-deficient mutant of this strain (E325ad1) as antagonist of Erwinia amylovora Ea153N in orchards of $\mathbf{A}$ and $\mathbf{C}$, 'Gale Gala' apple and B and D, 'Golden Supreme' apple in 2009. Population sizes are shown $\mathbf{A}$ and $\mathbf{B}$, for strains of $P$. agglomerans and $\mathbf{C}$ and $\mathbf{D}$, for the pathogen. Stigmas were inoculated with $P$. agglomerans at 0 days and with Ea153N at 2 days. Each point is the mean of five single-tree replicates, using the average of six flowers per tree, and vertical lines represent standard error.

TABLE 1. Relative area under the population curve (RAUPC) of antagonist Pantoea agglomerans E325, antibiosis-deficient mutants E325ad1 and E325ad2, and pathogen Erwinia amylovora Ea153N on flowers of apple and crab apple ${ }^{\mathrm{y}}$

\begin{tabular}{|c|c|c|c|c|c|c|c|c|c|}
\hline & \multirow[b]{3}{*}{ Year } & \multirow[b]{3}{*}{ Cultivar } & \multicolumn{7}{|c|}{ RAUPC for bacterial population size ${ }^{\mathrm{z}}$} \\
\hline & & & \multicolumn{3}{|c|}{ P. agglomerans } & \multicolumn{4}{|c|}{ E. amylovora Ea153N } \\
\hline & & & E325 & E325ad1 & E325ad2 & Water & E325 & E325ad1 & E325ad2 \\
\hline Laboratory & 2010 & Manchurian & $6.3 \mathrm{a}$ & $6.4 \mathrm{a}$ & $6.3 \mathrm{a}$ & $5.7 \mathrm{a}$ & $2.4 \mathrm{c}$ & $4.3 \mathrm{~b}$ & $4.3 \mathrm{~b}$ \\
\hline Orchard & 2009 & Gale Gala & $5.8 \mathrm{a}$ & $6.1 \mathrm{a}$ & NT & $5.4 \mathrm{a}$ & $3.4 \mathrm{~b}$ & $5.1 \mathrm{a}$ & NT \\
\hline Orchard & 2009 & Golden Supreme & $6.4 \mathrm{a}$ & $6.5 \mathrm{a}$ & NT & $5.5 \mathrm{a}$ & $2.5 \mathrm{c}$ & $4.2 \mathrm{~b}$ & NT \\
\hline Orchard & 2010 & Royal Gala & $6.5 \mathrm{a}$ & $6.6 \mathrm{a}$ & $6.5 \mathrm{a}$ & $5.4 \mathrm{a}$ & $3.3 \mathrm{~b}$ & $5.1 \mathrm{a}$ & $5.2 \mathrm{a}$ \\
\hline
\end{tabular}

y Experiments were performed in the laboratory with 10 single-flower replications per sample date (five per each of two trials pooled) or in the orchard with five single-tree replications. All flowers used were newly opened at start of experiment when suspensions of P. agglomerans strains were applied at $10^{8} \mathrm{CFU} / \mathrm{ml}$ (with pipet in laboratory; artist brush or sterile swab in orchard). After $48 \mathrm{~h}$, the pathogen Ea153N was similarly applied at $10^{7} \mathrm{CFU} / \mathrm{ml}$.

${ }^{\mathrm{z}}$ RAUPC was calculated as described in Materials and Methods. NT = not tested. Means within a row, for antagonist or pathogen, followed by the same letter are not significantly different according to least significant difference test $(P=0.05)$. 
to, or greater than, the parental strain. The colony morphology of the mutants differed, with each being stable and representative of only one of two morphologies displayed in the parental strain. While this phenotypic dichotomy is not understood, it is of interest that hypermucoidy in one mutant did not prove to be an epiphytic advantage as might be expected $(4,21)$ under the relatively dry conditions of orchard trials. The antagonist E325 established mean populations in excess of $10^{6} \mathrm{CFU}$ per flower by 3 or 4 days after application and suppressed growth of the pathogen $E$. amylovora on stigmas in each experiment, consistent with previous studies $(24,26,27,30)$. Despite the epiphytic fitness of mutants E325ad1 and E325ad2 on stigmatic surfaces, the mutants were less effective than the parental strain in growth suppression of E. amylovora on stigmas. A comparison of the antibiosisdeficient mutants with parental E325 in PSBM broth revealed no differences in acidification, which was previously reported as a possible mechanism of E325 in the suppression of E. amylovora (30).

Antibiosis was previously implicated as a mode of antagonism by Pantoea strains Eh252 (39), Eh318 (47), and Eh1087 (7) on flowers; however, the antibiotic of strain E325 exhibits activity that is unique from antibiotics in these reports. The E325 compound has an unusual sensitivity to alkaline and high-phosphate conditions, but at the same time is not affected by amino acids, such as histidine, which reverses antibiosis by Eh252 (45), C9-1 (11), and Eh318 (47). The antibiotic of E325 also is unaffected by a number of enzymes, including proteases known to inhibit the antibiotic of strain Eh252 (45) and C9-1 (1) or $\beta$-lactamase, reported to inactivate the phenazine compound of Eh1087 (17). In addition, the E325 antibiotic has a high specificity to E. amylovora, showing no activity toward other bacterial species tested thus far (30). By contrast, other antibiotics of Pantoea species reportedly inhibit a spectrum of other microorganisms (11,17, 45,47).

Given that epiphytic growth of E. amylovora on flowers, particularly the stigma, is closely related to the risk and incidence of fire blight $(2,13,15)$, we focused on pathogen suppression by E325 and its antibiosis-deficient derivative strains on stigmatic

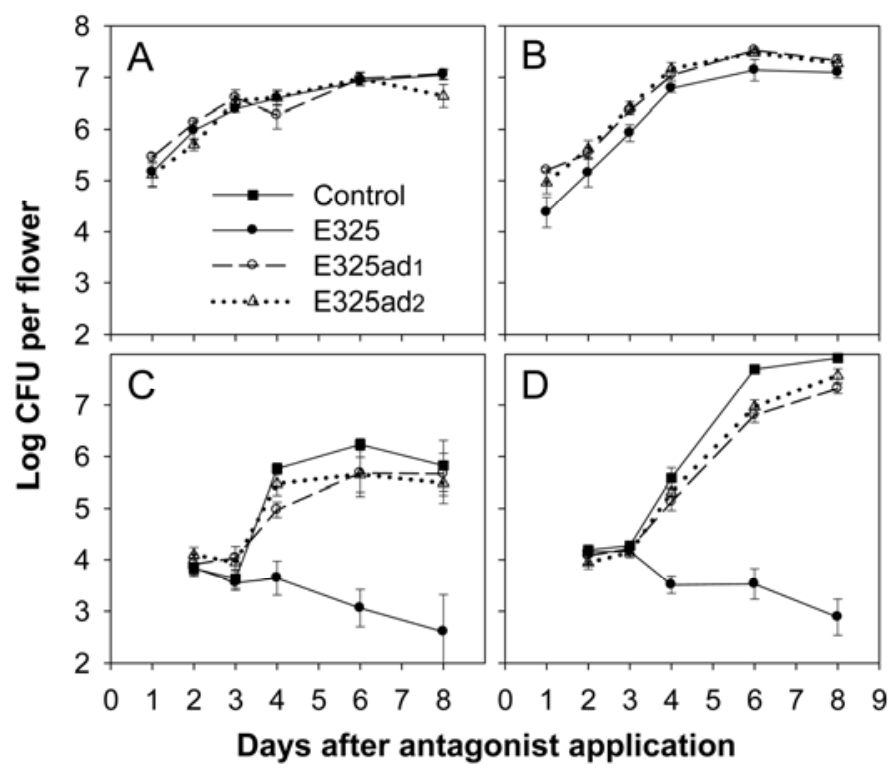

Fig. 5. Comparison of Pantoea agglomerans E325 with two antibiosisdeficient mutants of this strain (E325ad1 and E325ad2) as antagonists of Erwinia amylovora Ea153N in orchards of $\mathbf{A}$ and $\mathbf{C}$, 'Royal Gala' apple and $\mathbf{B}$ and D, 'Cameo' apple in 2010. Population sizes are shown A and B, for strains of P. agglomerans and $\mathbf{C}$ and $\mathbf{D}$, for the pathogen. Stigmas were inoculated with P. agglomerans at 0 days and with Ea153N at 2 days. Each point is the mean of five single-tree replicates, using the average of six flowers per tree, and vertical lines represent standard error. surfaces. Variables were minimized under controlled laboratory conditions and in the orchard by directly inoculating selected flowers of one age. The field approach also minimizes cross contamination of treatments by drift and insect pollinators $(26,27,30)$. The experiments, however, are not representative of commercial practices, and some aspects of the results are not comparable to a similar orchard study with $P$. agglomerans Eh252 (39) in which whole trees were treated with bacterial suspensions using backpack sprayers. For example, the previous study compared incidence of establishment of bacterial populations, a factor of little relevance in the present investigation, since all flowers used were newly opened, directly treated, and highly conducive to bacterial colonization.

Both in the laboratory and field, the antibiosis-deficient mutants of E325 sometimes grew slightly better than the parent strain based on comparisons of mean population sizes on single sampling dates or mean RAUPC values. An increase in mutant growth may relate to the redirection of energy gained from eliminating antibiotic production or localized infections on stigmas and styles by nonsuppressed populations of E. amylovora (12). The latter conjecture is consistent with in vitro tests which, in the absence of the pathogen, resulted in no differences in growth of E325 and mutant strains (Fig. 6). None of the flower experiments generated evidence indicating that epiphytic fitness of the antibiosis-deficient mutants on flower stigmas was compromised by the Tn 5 insertion. Thus, differences in pathogen suppression by E325 and the mutant strains are likely due to differences in antibiosis rather than in colonization of stigmatic surfaces. Although the mutants are morphologically distinct on certain artificial media, i.e., E325ad1 exhibits a smooth and butyrous colony type whereas E325ad2 is hypermucoid and viscous, experimental results with flowers did not indicate a relationship between these characteristics and microbial fitness on stigmas. The hypermucoid
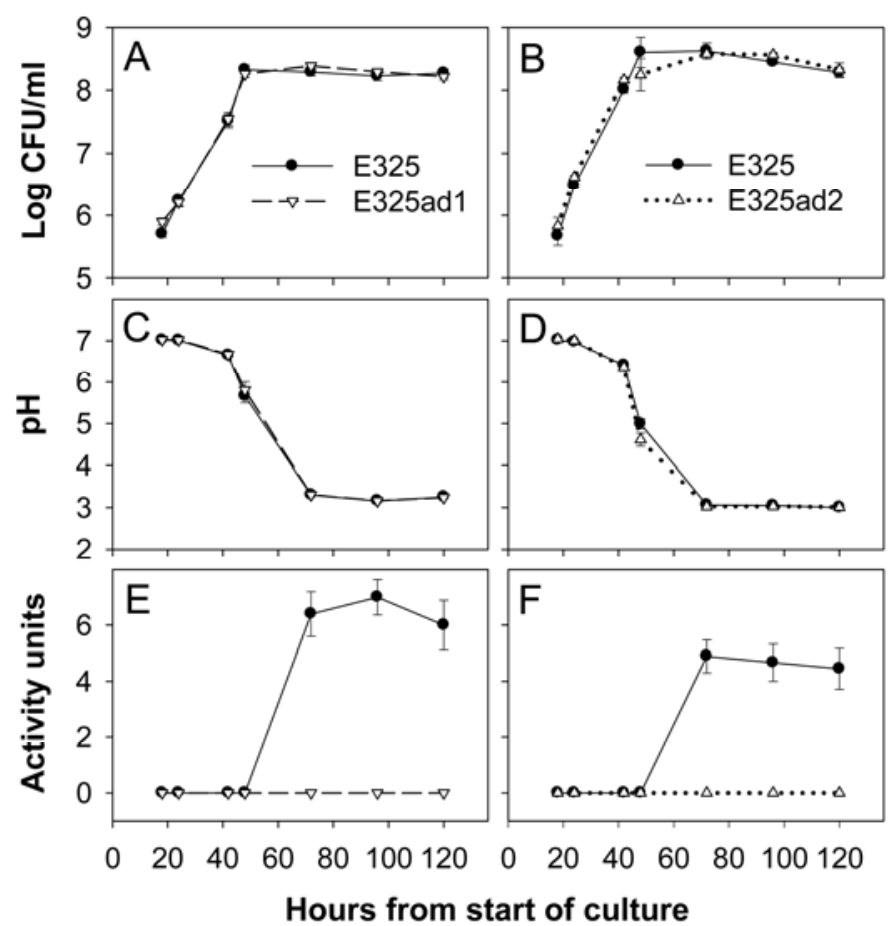

Fig. 6. Interrelationship of in vitro growth, acid production, and antibiotic production by Pantoea agglomerans strain E325 and antibiosis-deficient mutants in liquid partial stigma-based medium. Data are presented for $\mathbf{A}$ and $\mathbf{B}$, population size, $\mathbf{C}$ and $\mathbf{D}, \mathrm{pH}$, and $\mathbf{E}$ and $\mathbf{F}$, antibiotic production over time at $14^{\circ} \mathrm{C}$. Left panels $(\mathbf{A}, \mathbf{C}$, and E) compare E325 with derivative E325ad1 and right panels (B, D, and F) compare E325 with derivative E325ad2. Each point is the mean of six or nine replicate cultures, and vertical lines represent standard error. 
characteristic of E325ad2 was not advantageous on flowers, even under the dry orchard conditions in which overall average relative humidity was only $45 \%$. While formation of extracellular polysaccharides (EPS) is known to contribute to the survival and epiphytic fitness of bacteria on leaves $(4,21)$, possibly EPS is not produced by, or advantageous to, bacteria supported on moist surfaces of pomaceous stigmas that exude glycoproteins, sugars, and other substances (28).

The $P$. agglomerans E325 mutants E325ad1 and E325ad2 reduced the RAUPC of E. amylovora compared with the growth dynamics of the pathogen on water-treated flowers in four out of six experiments (Table 1). This was similar to results reported by Stockwell et al. (39), indicating that the antibiotic-deficient mutant of Eh252 reduced the RAUPC of the pathogen in four out of seven trials. Like P. agglomerans strains Eh318 (47) and Eh252 (39), antibiotic production is not the only mode of antagonism by E325. Additional biocontrol mechanisms proposed for P. agglomerans include competitive exclusion and habitat modification $(13,42)$.

Early fire blight researchers $(6,8,33)$ suggested that bacteria now identified as Pantoea spp. suppressed E. amylovora on apple and pear trees by producing acid, since the nonpathogenic bacteria also reduced the $\mathrm{pH}$ in vitro to below the optimal range of pH 6 to 7 for pathogen growth $(8,46)$. The hypothesis that Pantoea spp. suppresses fire blight solely by acidification of microhabitats was not supported, however, by later studies involving pear fruit tissue (46), where $\mathrm{pH}$ and the capacity of strains to inhibit the pathogen were not correlatively related. Acidification by $P$. agglomerans on flowers was recently investigated for the first time (30), prompted initially by an inability to detect antibiotic production. E325 slightly increased the acidity on flowers, based on the $\mathrm{pH}$ in bulked stigma exudates extracted from inoculated flowers, and thus acidification possibly contributed to pathogen suppression. However, until direct methods are available for measuring $\mathrm{pH}$ at specific sites where E325 has colonized stigmatic surfaces, we cannot accurately assess the importance of acidification alone in the suppression of E. amylovora on flowers.

The antibiosis-deficient mutants of E325 acidified PSBM similarly to the parental strain, and thus allow for examination of the role of acidification independent of antibiosis in suppression of E. amylovora. In this study, acidification of the stigma habitat may contribute to suppression of the pathogen, considering that the RAUPC of E. amylovora was lower on flowers treated with the mutants compared with flowers treated with water. The slight suppression of the pathogen by the mutants, however, also may be due to preemptive exclusion and competition. Most importantly, the mutants were less effective in suppression of E. amylovora compared to the parental strain, leading to the conclusion that the antibiotic of E325 is produced and is active on stigmas and that it contributes to pathogen suppression.

We suggest that acidification may play an indirect role in suppression of fire blight by E325. Mean pH values in PSBMbroth cultures of E325 were never different from those of E325ad1 or E325ad2 during the sampling period. Since the antibiosis-deficient mutants acidified the medium, biosynthesis of the antibiotic of E325 is likely not responsible for acidification that may occur in microhabitats. The antibiotic rapidly and irreversibly loses activity under alkaline conditions (30). We propose that acidification of the stigma habitat by E325 favors stability and activity of the antibiotic for optimal suppression of $E$. amylovora.

We noted that during early stationary phase of E325, a dramatic reduction in $\mathrm{pH}$ occurred between one sample when the antibiotic was undetected, based on antibiosis assays, and the next sample when the antibiotic was detected at relatively high levels. This is comparable to the relationship between $\mathrm{pH}$ and the production of herbicolin A by P. agglomerans strain A111 (9). Unlike the E325 compound, however, herbicolin A production increased during the exponential phase of bacterial growth. The timing of antibiotic production by E325 and stability of the compound under acidic conditions during stationary phase may explain in part why differences in pathogen responses to E325 and the antibiosis-deficient mutants on apple flowers were greatest during late sampling dates when population sizes of these strains no longer increased. Additional research is required to determine whether antibiosis is regulated by the stationary phase gene $r p o S$ or other quorumsensing systems. The temporal dynamics of antibiotic production of E325 relative to growth phase is worth consideration when selecting antagonist or antagonist mixtures (13) for fire blight management, since an early production of inhibitory compounds may be advantageous for suppression of the pathogen.

\section{ACKNOWLEDGMENTS}

We thank J. Duffy, B. Steady, and T. Culbertson for technical assistance and Van Well Nursery for providing trees. Funding was provided by the USDA-CSREES and the Swiss Federal Office of Agriculture (BLW FOAG, Fire Blight Pathogen Biocontrol Project).

\section{LITERATURE CITED}

1. Anderson, L. M., Stockwell, V. O., and Loper, J. E. 2004. An extracellular protease of Pseudomonas fluorescens inactivates antibiotics of Pantoea agglomerans. Phytopathology 94:1228-1234.

2. Billing, E. 2000. Fire blight risk assessment systems and models. Pages 235-252 in: Fire Blight: The Disease and Its Causative Agent, Erwinia amylovora. J. L. Vanneste, ed. CAB International, Wallingford, UK.

3. Bogs, J., Bruchmüller, I., Erbar, C., and Geider, K. 1998. Colonization of host plants by the fire blight pathogen Erwinia amylovora marked with genes for bioluminescence and fluorescence. Phytopathology 88:416-421.

4. Danhorn, T., and Fuqua, C. 2007. Biofilm formation by plant-associated bacteria. Annu. Rev. Microbiol. 61:401-422.

5. El-Masry, M. H., Brown, T. A., Epton, H. A. S., and Sigee, D. C. 1997. Transfer from Erwinia herbicola to Escherichia coli of a plasmid associated with biocontrol of fire blight. Plant Pathol. 46:865-870.

6. Farabee, G. J., and Lockwood, J. L. 1958. Inhibition of Erwinia amylovora by Bacterium sp. isolated from the fire blight cankers. Phytopathology 48:209-211.

7. Giddens, S. R., Houliston, G. J., and Mahanty, H. K. 2003. The influence of antibiotic production and pre-emptive colonization on the population dynamics of Pantoea agglomerans (Erwinia hericola) Eh1087 and Erwinia amylovora in planta. Environ. Microbiol. 5:1016-1021.

8. Goodman, R. N. 1965. In vitro and in vivo interactions between components of mixed bacterial cultures isolated from apple buds. Phytopathology 55:217-221.

9. Greiner, M., and Winkelmann, G. 1991. Fermentation and isolation of herbicolin A, a peptide antibiotic produced by Erwinia herbicola strain A 111. Appl. Microbiol. Biotechnol. 34:565-569.

10. Ishimaru, C., and Klos, E. J. 1984. New medium for detecting Erwinia amylovora and its use in epidemiological studies. Phytopathology 74:1342-1345.

11. Ishimaru, C. A., Klos, E. J., and Brubaker, R. R. 1988. Multiple antibiotic production by Erwinia herbicola. Phytopathology 78:746-750.

12. Johnson, K. B., Sawyer, T. L., Stockwell, V. O., and Temple, T. N. 2009. Implications of pathogenesis by Erwinia amylovora on rosaceous stigmas to biological control of fire blight. Phytopathology 99:128-138.

13. Johnson, K. B., and Stockwell, V. O. 2000. Biological control of fire blight. Pages 319-337 in: Fire Blight: The Disease and Its Causative Agent, Erwinia amylovora. J. L. Vanneste, ed. CAB International, Wallingford, UK.

14. Johnson, K. B., Stockwell, V. O., Burgett, D. M., Sugar, D., and Loper, J. E. 1993. Dispersal of Erwinia amylovora and Pseudomonas fluorescens by honey bees from hives to apple and pear blossoms. Phytopathology 83:478-484.

15. Johnson, K. B., Stockwell, V. O., and Sawyer, T. L. 2004. Adaptation of fire blight forecasting to optimize the use of biological controls. Plant Dis. 88:41-48.

16. Kanehisa, M., Goto, S., Kawashima, S., and Nakaya, A. 2002. The KEGG databases at GenomeNet. Nucleic Acids Res. 30:42-46.

17. Kearns, L. P., and Hale, C. N. 1996. Partial characterization of an inhibitory strain of Erwinia herbicola with potential as a biocontrol agent for Erwinia amylovora, the fire blight pathogen. J. Appl. Bacteriol. 81:369-374. 
18. King, E. O., Ward, M. K., and Raney, D. E. 1954. Two simple media for the demonstration of pyocyanin and fluorescin. J. Lab. Clin. Med. 44:301307.

19. Lindow, S. E. 1985. Integrated control and role of antibiosis in biological control of fire blight and frost injury. Pages 83-115 in: Biological Control on the Phylloplane. C. Windels and S. E. Lindow, eds. American Phytopathological Society, St. Paul, MN.

20. Meyer, F., Goesmann, A., McHardy, A. C., Bartels, D., Bekel, T., Clausen, J., Kalinowski, J., Linke, B., Rupp, O., Giegerich, R., and Pühler, A. 2003. GenDB-an open source genome annotation system for prokaryote genomes. Nucleic Acids Res. 31:2187-2195.

21. Morris, C. E., Barnes, M. G., and McLean, J. C. 2002. Biofilms on leaf surfaces: Implications for the biology, ecology and management of populations of epiphytic bacteria. Pages 139-155 in: Phyllosphere Microbiology. S. E. Lindow, E. I. Hecht-Poinar, and V. J. Elliot, eds. American Phytopathological Society, St. Paul, MN.

22. Pasquer, F., Pelludat, C., Duffy, B., and Frey, J. E. 2010. Broad spectrum microarray for fingerprint-based bacterial species identification. BMC Biotechnol. 10:13.

23. Psallidas, P. G., and Tsiantos, J. 2000. Chemical control of fire blight. Pages 199-234 in: Fire Blight: The Disease and Its Causative Agent, Erwinia amylovora. J. L. Vanneste, ed. CAB International, Wallingford, UK.

24. Pusey, P. L. 1997. Crab apple blossoms as a model for research on biological control of fire blight. Phytopathology 87:1096-1102.

25. Pusey, P. L. 1999. Laboratory and field trials with selected microorganisms as biocontrol agents for fire blight. Acta Hort. 489:655-661.

26. Pusey, P. L. 2002. Biological control agents for fire blight of apple compared under conditions limiting natural dispersal. Plant Dis. 86:639644.

27. Pusey, P. L., and Curry, E. A. 2004. Temperature and pomaceous flower age related to colonization by Erwinia amylovora and antagonists. Phytopathology 94:901-911.

28. Pusey, P. L., Rudell, D. R., Curry, E. A., and Mattheis, J. P. 2008. Characterization of stigma exudates in aqueous extracts from apple and pear flowers. HortScience 43:1471-1478.

29. Pusey, P. L., Stockwell, V. O., and Mazzola, M. 2009. Epiphytic bacteria and yeasts on apple blossoms and their potential as antagonists of Erwinia amylovora. Phytopathology 99:571-581.

30. Pusey, P. L., Stockwell, V. O., and Rudell, D. R. 2008. Antibiosis and acidification by Pantoea agglomerans strain E325 may contribute to suppression of Erwinia amylovora. Phytopathology 98:1136-1143.

31. Rezzonico, F., Pflüger, V., Vogel, G., Tonolla, M., and Duffy, B. 2010. Whole cell MALDI-TOF mass spectrometry for rapid identification and clustering of Pantoea species. Appl. Environ. Microbiol. 76:4497-4509.

32. Rezzonico, F., Smits, T. H. M., Montesinos, E., Frey, J. E., and Duffy, B.
2009. Genotypic comparison of Pantoea agglomerans plant and clinical strains. BMC Microbiol. 9:204.

33. Riggle, J. H., and Klos, E. J. 1972. Relationship of Erwinia herbicola to Erwinia amylovora. Can. J. Bot. 50:1077-1083.

34. Sambrook, J., and Russell, D. W. 2001. Molecular Cloning: A Laboratory Manual. 3rd ed. Cold Spring Harbor Laboratory, Cold Spring Harbor, NY.

35. Shaner, G., and Finney, R. E. 1977. The effect of nitrogen fertilization on the expression of slow-mildewing resistance in Knox wheat. Phytopathology 67:1051-1056.

36. Smits, T. H. M., Rezzonico, F., Kamber, T., Blom, J., Goesmann, A., Frey, J. E., and Duffy, B. 2010. Complete genome sequence of the fire blight bacterium Erwinia amylovora CFBP 1430 and comparison to other Erwinia strains. Mol. Plant-Microbe Interact. 23:384-393.

37. Smits, T. H. M., Rezzonico, F., Kamber, T., Goesmann, A., Ishimaru, C. A., Stockwell, V. O., Frey, J. E., and Duffy, B. 2010. Complete genome sequence of Pantoea vagans plant-beneficial strain C9-1. J. Bacteriol. 192:6486-6487.

38. Smits, T. H. M., Rezzonico, F., Pelludat, C., Goesmann, A., Frey, J. E., and Duffy, B. 2010. Genomic and phenotypic characterization of a nonpigmented variant of Pantoea vagans biocontrol strain C9-1 lacking the 530-kb megaplasmid pPag3. FEMS Microbiol. Lett. 308:48-54.

39. Stockwell, V. O., Johnson, K. B., Sugar, D., and Loper, J. E. 2002. Antibiosis contributes to biological control of fire blight by Pantoea agglomerans strain Eh252 in orchards. Phytopathology 92:1202-1209.

40. Stockwell, V. O., Temple, T. N., Johnson, K. B., and Loper, J. E. 2008. Integrated control of fire blight with antagonists and oxytetracycline. Acta Hort. 793:383-390.

41. Thomson, S. V. 1986. The role of the stigma in fire blight infections. Phytopathology 76:476-482.

42. Vanneste, J. L. 1996. Honey bees and epiphytic bacteria to control fire blight, a bacterial disease of apple and pear. Biocontrol News Information $17: 67 \mathrm{~N}-78 \mathrm{~N}$.

43. Vanneste, J. L. (ed.) 2000. Fire Blight: The Disease and Its Causative Agent, Erwinia amylovora. CAB International, Wallingford, UK

44. Vanneste, J. L., Cornish, D. A., Yu, J., and Voyle, M. D. 2002. P10c: A new biological control agent for control of fire blight which can be sprayed or distributed using honey bees. Acta Hort. 590:231-235.

45. Vanneste, J. L., Yu, J., and Beer, S. V. 1992. Role of antibiotic production by Erwinia herbicola Eh252 in biological control of Erwinia amylovora. J. Bacteriol. 174:2785-2796.

46. Wodzinski, R. S., Umholtz, T. E., Rundle, J. R., and Beer, S. V. 1994. Mechanisms of inhibition of Erwinia amylovora by E. herbicola in vitro and in vivo. J. Appl. Bacteriol. 76:22-29.

47. Wright, S. A. I., Zumoff, C. H., Schneider, L., and Beer, S. V. 2001. Pantoea agglomerans strain Eh318 produces two antibiotics that inhibit Erwinia amylovora in vitro. Appl. Environ. Microbiol. 67:284-292. 